УДК 378:02]:006(477)(045)

DOI:

Галина Білавич, доктор педагогічних наук, професор кафедри педагогіки початкової освіти

ДВНЗ “Прикарпатський національний університет імені Василя Стефаника”

\title{
МОВНО-КОМУНІКАТИВНИЙ АСПЕКТ ПІДГОТОВКИ БАКАЛАВРІВ ІНФОРМАЦЙНОЇ, БІБЛІОТЕЧНОЇ ТА АРХІВНОЇ СПРАВИ КРІЗЬ ПРИЗМУ НАВЧАЛЬНО-МЕТОДИЧНОГО ЗАБЕЗПЕЧЕННЯ ГАЛУЗІ
}

Розглянуто питання підготовки бакалаврів спеиіальності 029 "Інформаційна, бібліотечна та архівна справа”. Проаналізовано навчально-методичне забезпечення, з'ясовано, щчо у змісті підготовки фахівців бібліотечно-інформаційної галузі переважає інформаційна парадигма. 3-поміж чинників, які впливають на освітні прочеси, виокремлено модернізацію системи підготовки кадрів, зокрема введення з 2016 р. року спеціальності “Інформаційна, бібліотечна та архівна справа”. За результатами аналізу навчальних планів зроблено висновок про недостаню реалізацію мовно-комунікативного аспекту, наголомено на посиленні ролі дисциплін мовно-літературного ичклу у формуванні комунікативної компетенції бакалаврів інформаційної, бібліотечної та архівної справи.

Ключові слова: інформачійна; бібліотечна та архівна справа; мовна культура; студенти; навчальнометодичне забезпечення.

Jim. 6.

Halyna Bilavych, Doctor of Sciences (Pedagogy), Professor of the Pedagogy of Preschool Education Department State Pedagogical University "Vasyl Stefanyk Precarpathian National University"

\section{LANGUAGE AND COMMUNICATION ASPECTS OFTHE TRAINING OF BACHELORS IN THE INFORMATIONAL, LIBRARY AND ARCHIVE SPHERES THROUGH THE PRISM OF EDUCATIONAL AND METHODAL PROVISION OF THE INDUSTRY}

The question of training of specialists of the informational activities area is always on time. Especially it became important because of creating a new and complex speciality 029 "Library studies, Science of Bibliography and Information work", which prevails information paradigm in the content. Informational Paradigm of training of specialists in "Library studies, Science of Bibliography and Information work" develops under the influence of a number of external and internal factors. To internal factors we should include the modernization of professional trainings, particularly creating of the speciality "Library studies, Science of Bibliography and Information work" in 2016; creating the educational programs for this speciality for Bachelor and Master levels on the basis of combining the practice-oriented study and trainings which are based on researchings; strengthening cooperation with different kinds of informational institutions as bases of getting the practicing skills and creating the University Centres of Practical Competences.

An adoption of the standard of higher education in Ukraine of the specialty 029 "Information, Library and Archival business" led to the need of finding the ways that would allow the educational process to form the subject of learning a set of competencies defined by the standard, which are currently determined by the final results of study in a higher educational institution. In accordance with the requirements of the present, the professional training of future specialists in this field is characterized by multifunctionality, covering integrated in the specialty of the sphere of activity, which led to the expansion of both the theoretical and substantive and practical content of education. The scientific and methodological support in the process of professional development of the future specialist reflects the content and methodological essence of learning and promotes the efficiency of its organization. Creation of new scientific and methodological support in order to ensure qualitative training of future specialists initiates the consideration of different approaches for optimal solution of the tasks in accordance with the content of educational and professional training.

Keywords: an informational, library and archival business, a language culture, the students, the scientificmethodic provision.

П остановка проблеми. Актуальність порушеної в назві статті теми зумовлена низкою чинників, ідеться насамперед про зростання ролі культури української мови у становленні професійної компетентності майбутнього фахівця інформаційної, бібліотечної та архівної справи та формуванні його як національно-мовної особистості, що передбачає формування позитивної мовної поведінки студентів у процесі ефективної наукової, освітньої, практичної діяльності. 


\section{МОВНО-КОМУНІКАТИВНИЙ АСПЕКТППДГОТОВКИ БАКАЛАВРІВ ІНФОРМАЦЙНОӦ,БІБЛІОТЕЧНОЇ ТА АРХІВНОӤ СПРАВИ КРІЗЬ ПРИЗМУ НАВЧАЛЬНО-МЕТОДИЧНОГОЗАБЕЗПЕЧЕННЯ ГАЛУЗІ}

В Україні тривають пошуки шляхів розв'язання проблеми професійної підготовки майбутніх спеціалістів інформаційної, бібліотечної та архівної справи, яка адаптується до вимог сучасної бібліотечно-інформаційної освіти, зарубіжного досвіду тощо. Відповідно до Постанови Кабінету Міністрів України №266 від 29 квітня 2015 року “Про затвердження переліку галузей знань i спеціальностей, за якими здійснюється підготовка здобувачів вищої освіти", спеціальність “інформаційна, бібліотечна та архівна справа" (код спеціальності належить до галузі знань “Культура і мистецтво” (шифр галузі № 02) є інтегрованою освітньою галуззю. Усе це детермінує певні зміни у змісті та технологіях професійного навчання фахівців з інформаційної, бібліотечної та архівної справи.

У цьому контексті актуальним є ширше включення до змісту освіти бакалаврів інформаційної, бібліотечної та архівної справи дисциплін мовознавчого циклу. Це пояснюємо низкою причин. Зокрема, сучасне інформаційне суспільство висуває нові вимоги до розвитку освіти щодо застосування інформації та використання нових інформаційних технологій. Значна роль відводиться бібліотекам як науковоінформаційним освітнім центрам. Змінюються вимоги суспільства до бібліотек як установ, які забезпечують доступ громадян до інформаційних джерел, надають інформаційні послуги, здійснюють інформаційний супровід різних видів людської діяльності, що впливає на розширення кола повноважень бібліотечних працівників. Відтак бібліотекарі, працівники архівів, інших закладів виконують функції професійних фахівців інформаційно-консультаційних центрів, що надають різноманітні послуги для всіх верств населення.

Новий професійний статус цих спеціалістів зумовлює потребупідготовки висококваліфікованих фахівців з інформаційної, бібліотечної та архівної справи, здатних створювати, зберігати та поширювати інформаційні ресурси, використовувати інформаційно-комунікаційні технології, працювати 3 документи, клієнтами тощо. Такому спеціалістові відводиться особливе місце в системі ринкових і виробничих відносин, налагодження комунікаційних зв'язків із партнерами, клієнтами, відвідувачами, колегами та ін. Оскільки спеціальність "Інформаційна, бібліотечна та архівна справа" належить до гуманітарного напряму підготовки, майбутні фахівці повинні не тільки фахово здійснювати відбір, аналіз, оцінку, систематизацію, моніторинг, організацію, зберігання, поширення інформації та знань у будь-яких форматах, а також мати повний набір компетентностей, передбачених для інтегрованої спеціальності 029 "Інформаційна, бібліотечна та архівна справа”, з-поміж яких комунікативна обізнаність. Важливим складником формування комунікативної компетенції бакалаврів інформаційної, бібліотечної та архівної справи $є$ формування мовленнєвого етикету.

Аналіз досліджень і публікацій. Предметом досліджень професійної підготовки фахівців спеціальності 029 "Інформаційна, бібліотечна та архівна справа” $є$ : розвиток вищої інформаційно-бібліотечної галузі у ХХІ ст. (В. Бабич, Н. Бачинська, Т. Новальська, Т. Павлуша, А. Соляник, О. Сербін, I. Тимошенко, Г. Швецова-Водка, Г. Шемаєва, Т. Ярошенко), концептуальні ідеї професійної бібліотечно-інформаційної освіти (А. Чачко, Л. Демчина, О. Кухтяк, А. Сидоренко, Ю. Трач); розвиток бібліотечної освіти в Україні (І. Конюкова); та ін. Утім, тему, порушену в назві статті, науковці грунтовно не досліджували.

Мета дослідження - проаналізувати навчально-методичне забезпечення підготовки бакалаврів спеціальності 029 "Інформаційна, бібліотечна та архівна справа” крізь призму формування комунікативної компетенції особистості.

Виклад основного матеріалу. В Україні триває процес випрацювання державних освітніх стандартів, зокрема й у галузі бібліотечноінформаційної освіти. Як слушно зазначають фахівці (А. Соляник, Я. Хіміч та ін.), важливою новацією в цьому контексті варто визнати оголошення Міністерством освіти й науки України відкритого конкурсу, який проводився 3-поміж представників науково-педагогічної громадськості 3ВО щодо обрання складу підкомісій Науковометодичної комісії з культури і мистецтва сектору вищої освіти Науково-методичної Ради Міністерства освіти і науки України. За результатами відкритого конкурсного відбору $з$ 16 претендентів, що подали на конкурс власні проекти стандартів, до складу роботи підкомісії зі спеціальності 029 "Інформаційна, бібліотечна та архівна справа” Науково-методичної комісії з культури і мистецтва було обрано 7 завідувачів профільних кафедр 3ВО Києва, Харкова, Львова, Тернополя, які до грудня 2016 р. розробили спільний проект стандарту галузевої освіти зі спеціальності 029 “Інформаційна, бібліотечна та архівна справа” та опублікували на офіційному сайті МОНУ для громадського обговорення. Уперше в історії розвитку бібліотечноінформаційної освіти відбувається колегіальне формування змісту та широке громадське 


\section{МОВНО-КОМУНІКАТИВНИЙ АСПЕКТПДГОТОВКИБАКАЛАВРІВ ІНФОРМАЦЙНӦ̈, БІБЛІОТЕЧНОЇ ТА АРХІВНОӤ СПРАВИ КРІЗЬ ПРИЗМУ НАВЧАЛЬНО-МЕТОДИЧНОГОЗАБЕЗПЕЧЕННЯ ГАЛУЗІ}

обговорення стандарту фахової освіти, цей процес істотно ускладнюється необхідністю гармонізації переліку професійних компетентностей майбутніх фахівців, що будуть навчатися в межах єдиної інтегрованої спеціальності [4, 12 - 13].

Погоджуємося 3 думкою науковця А. Соляник про те, що аналіз пропозицій та зауважень науковопедагогічної громадськості профільних вишів до проекту стандарту підготовки бакалавра зі спеціальності 029 "Інформаційна, бібліотечна та архівна справа” дозволив визначити наявність прямо протилежних методологічних підходів до визначення змісту фахових компетентностей майбутніх випускників: від штучного їх звуження в контексті посилення гуманістичнокультурологічної парадигми функціонування бібліотек і архівів як суто соціокультурних інституцій суспільства - до майже повного нівелювання особливостей цих видів документокомунікаційних структур в контексті культивування технологічно-технократичної парадигми розвитку глобального інформаційного суспільства [4, 12 - 13]. Окремі представники кафедр документознавчого спрямування деяких технічних вишів, які репрезентують бібліотечноінформаційну освіти, нині продовжують робити спроби теоретичного обгрунтування та практичної реалізації перейменування спеціальності 029 "Інформаційна, бібліотечна та 13 архівна справа" на "Документо-інформаційний сервіс" або розподілу їі на дві, що спрямовані на окрему підготовку бібліотекознавців та архівознавців, 3 одного боку, та документознавцівінформаціологів, з іншого [4, 12 - 13, 15].

Як варіант для подальшого колегіального обговорення переліку фундаментальних навчальних дисциплін підготовки бакалаврів за спеціальністю 029 “Інформаційна, бібліотечна та архівна справа” науковці пропонують такий перелік: “Інформаційні технологіі”, “Інформаційні системи та мережі”, “Аналітико-синтетична обробка документів”, “Загальне документознавство”, “Соціальні комунікації”, “Соціальна інформатика”, “Інформаційний менеджмент”, "Інформаційне право”, “Інформаційна етика та екологія”. До переліку інваріантної частини циклу професійних та практичних дисциплін відносять: “Архівознавство”, “Бібліотекознавство”, "Бібліографознавство”, “Організація інформаційноаналітичної діяльності”, “Інформаційний сервіс”, “Автоматизовані інформаційно-пошукові системи”, “Цифрові архіви та електронні бібліотеки”. Варіативна частина освітньої програми підготовки бакалавра, який навчається на спеціалізації “Бібліотечно-інформаційна діяльність", має передбачати вивчення студентами, починаючи 32 курсу, таких професійно орієнтованих навчальних дисциплін як “Книгознавство та історія книги", “Історія бібліотечної справи”, “Бібліотечне фондознавство”, "Бібліотечні інформаційно-пошукові системи", "Бібліотечно-інформаційний сервіс", “Автоматизовані інформаційно-бібліотечні системи”, “Системи електронних бібліотек та баз даних”, “Економіка бібліотечно-інформаційної діяльності”, “Бібліотечний менеджмент і маркетинг” та ін. Формуючи зміст цих дисциплін, важливо уникнути дублювання 3 тематичними модулями професійно орієнтованих дисциплін інваріантного блоку, розкрити організаційно-методичну та техніко-технологічну специфіку 16 функціонування традиційної та електронної бібліотеки як базового типу документокомунікаційної установи [4, 15]. Предмети мовно-літературного циклу становлять невеликий відсоток 3-поміж освітніх дисциплін.

Як уже йшлося, сучасне покоління стандартів освіти не передбачає переліку нормативних навчальних предметів, що закладають зміст підготовки майбутніх фахівців. Таким чином, перелік фундаментальних, професійно орієнтованих навчальних дисциплін, а також інваріантної частини навчальних предметів формують виші, які здійснюють підготовку бакалаврів спеціальності 029 "Інформаційна, бібліотечна та архівна справа”. Умовою підготовки, однак, має бути така вимога: зміст навчання має, з одного боку, бути спрямований на формування визначених стандартом освіти фахових компетентностей, які повинні орієнтуватися на найкращі європейські зразки, з іншого боку, ураховувати сучасні реалії освітньої теорії і практики, зокрема потребу підготовки національно-мовної особистості спеціаліста у галузі інформаційної, бібліотечної та архівної справи.

Такий перелік фундаментальних та професійно орієнтованих дисциплін інваріантної частини освітніх програм зі спеціальності 029 “Інформаційна, бібліотечна та архівна справа" має буги підсилений предметами мовно-літературного циклу. Це, на наше переконання, допоможе не тільки зберегти спадкоємність фахової підготовки різних освітніх рівнів, а й уможливить забезпечення процесу формування грунтовного професійного світогляду та системного переліку загальних фахових компетентностей у майбутніх бібліотекарів, інформаційних аналітиків та документознавців.

За результатами аналізу навчальних планів низки вишів (Київського університету імені Бориса 


\section{МОВНО-КОМУНІКАТИВНИЙ АСПЕКТ ПІДГОТОВКИ БАКАЛАВРІВ ІНФОРМАЦІЙНОЇ, БІБЛІОТЕЧНОЙ ТА АРХІВНОӤ СПРАВИ КРІЗЬ ПРИЗМУ НАВЧАЛЬНО-МЕТОДИЧНОГОЗАБЕЗПЕЧЕННЯ ГАЛУЗІ}

університету, Національного університету “Львівська політехніка", Східноєвропейського національного університету імені Володимира Даля, Національного транспортного університету, Державного університету телекомунікацій, ІваноФранківського національного технічного університету нафти і газу та ін.), які готують бакалаврів інформаційної, бібліотечної та архівної справи, 3'ясовано, що предмети мовнолітературного циклу по-різному представлені в навчальних планах цих 3ВО.

До прикладу, в документі “Освітньопрофесійна програма 029.00.02 Інформаційна, бібліотечна та архівна справа першого (бакалаврського) рівня вищої освіти" Київського університету імені Бориса Грінченка з-поміж загальних та спеціальних (фахових) компетентностей виокремлено такі: "Здатність застосовувати основи наукової роботи в бібліотечно-інформаційній галузі (підготовка аналітичних довідок, експрес-опитування, анкети). Складати та відповідним чином оформлювати накази, розпорядження, інші організаційні та довідковоінформаційні документи; брати участь у розробці положень про структурні підрозділи, посадових інструкцій; організовувати приймання матеріалів і документів, їх реєстрацію та облік”; “Здатність підтримувати ділову комунікацію 3 усіма суб'єктами інформаційного ринку, користувачами, партнерами, органами влади та управління, засобами масової інформаціі”; “Здатність працювати в команді. Здатність спілкуватися 3 представниками інших професійних груп різного рівня (з експертами 3 інших галузей знань/видів економічної діяльності)”; “Здатність забезпечувати відбір, аналіз, оцінку, систематизацію, моніторинг, організацію, зберігання, розповсюдження та надання в користування інформації та знань у будь-яких форматах. Аналітико-синтетична обробка документів та інформації, готувати відповідні аналітичні огляди, реферати наукових статей і монографій” [1].

Однак у наступному підрозділі цього документа "Перелік компонентів освітньопрофесійної програми та їх логічна послідовність” ми знайшли тільки окремі дисципліни, які слугують формуванню цих компетенцій: “Документознавство”, “Наукові студії”. Ми не віднайшли навчальної дисципліни "Українська мова (за професійним спрямуванням)", яка $є$ базовою для вивчення у всіх закладах вищої освіти. Доречним також видається вивчення курсу “Основи наукових досліджень”. На нашу

думку, ці предмети передовсім спрямовані на розвиток національно-мовної особистості бакалавра інформаційної, бібліотечної та архівної справи.

Ці дисципліни вивчаються у Східноєвропейському національномууніверситеті імені Володимира Даля [6], де зміст підготовки бакалаврів відповідає державним вимогам щодо змісту, потребам ринку праці та особистісному розвитку майбутнього фахівця.

Формування комунікативної компетенції здійснюється засобами широкого спектру навчальних дисциплін у Мукачівському державному університеті [5]. Підготовку висококваліфікованих фахівців 3 інформаційної, бібліотечної та архівної справи, які володіють необхідними знаннями інноваційного характеру, уміннями їх практичного застосування, здатних розв'язувати складні завдання та проблеми в галузі культури і мистецтва, забезпечує вивчення цикл предметів соціально-гуманітарної підготовки (українська мова за професійним спрямуванням); цикл фундаментальної підготовки (документознавство, книгознавствота ін.); цикл професійної та практичної підготовки (основи наукових досліджень, діловодство, діловий етикет, інформаційноаналітична діяльність, документно-інформаційні комунікації, риторика, стилістика ділового мовлення, лінгвістичні основи документознавства, основи наукового редагування та ін.); курси за вибором вищого навчального закладу: бібліографія художньої літератури, інноваційнометодична робота в бібліотеці, теорія і практика референтської діяльності, бібліотечне краєзнавство, основи культури і техніки мовлення, ділові комунікації, практикум з української мови, наукова термінологія, літературне редагування; дисципліни вільного вибору студента: історія української літератури, сучасна українська література, етика ділового спілкування, практична стилістика та культура мовлення, історія зарубіжної літератури, сучасна зарубіжна література, сучасний літературний процес, соціологія книги і читання, дитяча література, сучасна дитяча література та ін. [5].

Як бачимо, тут домінує науковокультуроцентрично-бібіліографічно-літературномовна модель модернізації вищої інформаційнобібліотечної освіти (умовна назва). Перелічені вище дисципліни спроможні забезпечити не тільки процес формування національно-мовної особистості майбутнього бібліотекаря, а й підготовку його до виконання практичної діяльності як бібліотекаря (зокрема і шкільної бібліотеки) чи працівника видавничої чи 
книготорговельної справи, учасника дослідницьких проектів, автора наукових робіт. В основі цієї моделі - чотирикутник знань: культура (література, мова та ін.) - освіта - наука - інновації. Отже, для формування векторів інформаційно-бібліотечної освіти важливим виступає органічне поєднання гуманітарних знань (глибокі знання у ділянках культури, літератури, мови та ін.), медіаосвіти, технології автоматизованих бібліотечноінформаційних систем тощо.

Найширше дисципліни, які спрямовані на формування комунікативної компетенції майбутнього фахівця, присутні в навчальнометодичному забезпеченні технічних вишів. До прикладу, в Національному транспортному університеті вивчаються, окрім документознавства та подібних дисциплін, "Українська мова (за професійним спрямуванням)”, “Лінгвістичні основи документознавства (в т.ч. стилістика i редагування)", "Риторика" та ін. [2].

Метою бакалаврської програми Державного університету телекомунікацій, як зазначено в “Освітньо-професійній програмі “Документознавство та інформаційна діяльність” першого (бакалаврського) рівня вищої освіти галузі знань 02 "Культура" спеціальності 029 "Інформаційна, бібліотечна та архівна справа” (кваліфікація 3436.1 “Помічник керівника підприємства (установи, організації), референт”), є підготовка висококваліфікованих фахівців з документознавства та інформаційної діяльності у сфері управління. Студенти отримують освітню підготовку 3 документно-інформаційного забезпечення органів управління підприємств, установ, організацій на базі використання інноваційних технологій роботи 3 документними потоками та системами, усіма видами інформації [3]. Як засвідчив аналіз навчальної програми, мовно-комунікативний аспект підготовки фахівців забезпечується вивченням низки дисциплін: “Конфліктологія і теорія переговорів”, “Копірайтинг та основи редагування", “Спічрайтинг та риторика”, а також “Документна лінгвістика”, “Практикум зі стилістики та культури офісної документації” та ін.

Результати спостереження за мовним науковим середовищем низки вишів України, які готують фахівців спеціальності 029 "Інформаційна, бібліотечна та архівна справа”, дають підстави для висновку, що рівень наукового мовлення (як усного, так і писемного) є здебільшого середній, а то й низький. На наше глибоке переконання, однією зі спроб розв'язати цю проблему є виокремлення в самостійну навчальну дисципліну "Сучасне українське наукове мовлення" (як складник лінгвокультурології), вивчення якої варто пропонувати не тільки магістрам, а й студентам, що здобувають освітньо-кваліфікаційний рівень бакалавра спеціальності 029 "Інформаційна, бібліотечна та архівна справа”. 3 огляду на це майбутній документознавець, бібліотекар, референт тощо має знати не лише темарій курсу, який вивчає, а й основні ознаки і якості наукового мовлення, володіти фонетичними, орфоепічними, акцентуаційними, орфографічними, лексичними, словотвірними, синтаксичними, стилістичними, пунктуаційними нормами української мови, опанувати закони наукового мовлення. Окрім того, науковцеві-початківцю необхідно знати й основні стандарти, чинні нормативні документи щодо оформлення науково-дослідницьких робіт; слід набути умінь працювати 3 текстами наукового стилю, відшукувати необхідні для наукового дослідження відомості в сучасному інформаційному просторі.

Висновки та перспективи подальших досліджень. Отже, 3-поміж базових принципів державної освітньої політики України в галузі вищої освіти є відкритість формування структури і обсягу освітньої та професійної підготовки бакалаврів спеціальності 029 "Інформаційна, бібліотечна та архівна справа”, що спирається, зокрема, й на демократичні процедури колективного розроблення, широкого громадського обговорення та ухвалення стандартів освіти. Аналіз навчально-методичного забезпечення уможливив висновки про те, що узмісті підготовки фахівців бібліотечно-інформаційної галузі переважає інформаційна парадигма, недостатньо реалізовано мовно-комунікативний аспект формування професіограми майбутнього спеціаліста інформаційно-бібліотечної сфери. Тому подальших досліджень потребує питання пошуку шляхів формування комунікативної компетенції бакалаврів інформаційної, бібліотечної та архівної справи, один 3 них убачаємо в посиленні ролі дисциплін мовно-літературного циклу.

\section{ЛІТЕРАТУРА}

1. Київський університет імені Бориса Грінченка, освітньо-професійна програма. URL: http:// kubg.edu.ua.

2. Національний транспортний університет. URL: http:// www.ntu.edu.ua

3. Підготовка бакалаврів - кафедра документознавства та інформаційної діяльності. URL: http://www.dut.edu.ua/ ua/1735-pidgotovka-bakalavriv-kafedradokumentoznavstva-ta-informaciynoi-diyalnosti

4. Соляник А. А. Сучасні проблеми стандартизації вищої бібліотечно-інформаційної освіти в Україні // VII Міжнародна науково-практична конференція “Сучасна 


\section{ДИДАКТИЧНІ УМОВИ ФОРМУВАННЯ ІНДИВІДУАЛЬНИХ СТРАТЕГГЙ НАВЧАННЯ СТУДЕНТІВФІЛОЛОГІЧНИХ СПЕЦІАЛЬНОСТЕЙ}

інформаційно-бібліотечна освіта: європейські орієнтири": збірник матеріалів. - Електрон. вид. - Київ: УБА, 2017.-С.11-17.

5.029 "Інформаційна, бібліотечна та архівна справа" - Мукачівський державний університет. URL: http:// msu.edu.ua/wp-content/uploads/2017/07/ Б_02_029_ІБ.pdf

6. 6.020105 Документознавство-СНУ ім. В. Даля. URL: http:////snu.edu.ua/docs/univer/lic_and_acc/ snu_6_020105_documentoznavstvo.pdf

\section{REFERENCES}

1. Kyyivskyj universytet imeni Borysa Grinchenka, osvitno-profesijna programa [Kyiv Boris Grinchenko University, educational and professional program] Retrieved from http:// kubg.edu.ua. [in Ukrainian].

2.Nacionalnyj transportnyj universytet [National Transport University]. Retrieved from http:// www.ntu.edu.ua. [in Ukrainian].

3. Pidgotovka bakalavriv - kafedra dokumentoznavstva ta informacijnoyi diyalnosti [Preparation of bachelors Department of Documentation and Information Activity]
Retrieved from http://www.dut.edu.ua/ua/1735pidgotovka-bakalavriv-kafedra-dokumentoznavstva-tainformaciynoi-diyalnosti. [in Ukrainian]

4. Solyanyk, A. A. (2017). Suchasni problemy standartyzaciyi vyshhoyi bibliotechno-informacijnoyi osvity v Ukrayini [Modern Problems of Standardization of Higher Library and Information Education in Ukraine]. VII Mizhnarodna naukovo-praktychna konferentsiia "Suchasna informatsiino-bibliotechna osvita: yevropeiski oriientyry": zbirnyk materialiv - VII International Scientific and Practical Conference "Modern information and library education: European benchmarks": a collection of materials (pp. 11-17). Kyiv: UBA. [in Ukrainian].

5. 029 "Informacijna, bibliotechna ta arxivna sprava"Mukachivskyj derzhavnyj universytet ["Information, Library and Archives" - Mukachevo State University]. Retrieved from http://msu.edu.ua/wp-content/uploads/ 2017/07/B 02 029 IB.pdf. [in Ukrainian].

6. 6.020105 "Dokumentoznavstvo" - SNU im. V. Dalya ["Documentation" - SNU them. V. Dal]. Retrieved from http:// snu.edu.ua/docs/univer/lic_and_acc/snu _6 020105. [in Ukrainian].

Стаття надійшла до редакції 31.10.2018

УДК 378.147

DOI:

Олександр Малихін, доктор педагогічних наук, професор Національного університету біоресурсів та природокористування Украӥни, м. Київ Анастасія Гавриленко, аспірант кафедри англійської філологіi Чорноморського начіонального університету імені Петра Могили, м. Миколаїв

\section{ДИДАКТИЧНІ УМОВИ ФОРМУВАННЯ ІНДИВІДУАЛЬНИХ СТРАТЕГІЙ НАВЧАННЯ СТУДЕНТІВ ФІЛОЛОГІЧНИХ СПЕЦАЛЬНОСТЕЙ}

У статті визначено та описано дидактичні умови формування індивідуальних стратегій навчання студентів філологічних спеціальностей. Обтрунтовано оптимальність дидактичних умов, щзо сприятимуть продуктивності та оптимізаиії навчального проиесу в системі структурно-функиіональних елементів моделі формування індивідуальних стратегій навчання студентів-філологів. Проаналізовано провідну та супідрядні дидактичні умови формування індивідуальних стратегій навчання. Серед дидактичних умов, щяо гарантують успішне формування індивідуальних стратегій, визначені такі: реалізація положень компетентнісного підходу; забезпечення сталої мотивації суб 'єкта навчання; розробка індивідуальних освітніх траєкторій; реалізація індивідуальних траєкторій навчання за рахунок урахування індивідуально-особистісних стилів.

Ключові слова: дидактичні умови; метод навчання; індивідуальна стратегія; індивідуальна стратегія навчання; вивчення іноземних мов.

Лim. 6.

Oleksandr Malykhyn, Doctor of Sciences (Pedagogy), Professor, National University of Bioresources and Natural Resources of Ukraine, Kyiv Anastasiya Havrylenko, Postgraduate Student of the English Philology Department National Petro Mohyla Chornomorskiy University, Mykolayiv

\section{THE DIDACTIC CONDITIONS OF THE INDIVIDUAL LEARNING STRATEGIES FORMATION OF PHILOLOGY STUDENTS}

The article determinates and analyzes the didactic conditions for the formation of individual learning strategies of philology students. The optimality of didactic conditions, which will stimulate productivity and optimization of the educational process in the term of structural and functional elements of the model of formation individual learning strategies of philology students, is described. The leading and subordinate didactic conditions for the formation of individual learning strategies are analyzed. Didactic conditions as an element of didactic system are 